\title{
CASH FLOW MANAGEMENT IN THE CONTEMPORARY WAYS OF CONDUCTING BUSINESS IN THE REPUBLIC OF SERBIA
}

\author{
Marko Milojević ${ }^{1}$, Dragan Miletić ${ }^{2}$ \\ ${ }^{1}$ Faculty of Business in Belgrade, Singidunum University, Belgrade, Serbia \\ ${ }^{2}$ Schneider Electric DMS NS, Novi Sad, Serbia
}

\begin{abstract}
:
Modern management in companies assumed and cash flow management as one of the most important instruments for monitoring and controlling the normal functioning of the business. dequate cash flow management is based on the proper compiling cash flow statement and its interpretation. To determine the adequacy of the use of this report and the importance attached to managing cash flows, as universally applicable knowledge and skills, research was performed in local companies through a survey. The influence of different profiles cash needs of companies in relation to different aspects of the analysis of the cash flows. The results indicate that respondents with continuous and seasonal profiles cash needs have satisfactory knowledge of the subject research and the views that are completely or partially affirmative with respect to: future cash flows as a major determinant of the value of the enterprise, the positions of complementarity statements of cash flows in compared to the income statement and balance sheet. Companies that are not profiled your cash needs in the questionnaire stated disagreement with the above paragraphs, which represents a statement of their insufficient level of knowledge of the cash basis of financial reporting. Illiquidity of the domestic economy and the existing situation dictate the necessity of raising the quality of knowledge and skills in managing cash flows based on quality statements of cash flows and accompanying analysis.
\end{abstract}

\author{
Key words: \\ cash flow management, \\ cash flow analysis, \\ cash flow statement, \\ cash requirements profile \\ businesses, \\ future cash flows, \\ complementarity.
}

\section{INTRODUCTION}

Financial aspect of company management implies certain obligations to be fulfilled by managers. The most important of them being the understanding of the two bases for financial reporting: accounting and cash (monetary). Whereas the first is based on the elements of balance sheet and income statement, the business operations involving cash imply monitoring and analysis of cash flows and preparation of the Cash Flow Statement. This paper discusses the role which the cash generation activities have on business and deals with the influence which different cash requirements have on different aspects of cash flow and preparation of cash flow statements. Since 70s of the last century, members of international academic public have published several papers dealing with cash flow and methodology used to prepare cash flow statement. Bankruptcy of many companies across the world was the result of inadequate analysis of cash flow, illiquidity and insolvency. All of this practically leads to the conclusion that not enough attention is paid to cash management by modern companies. Practical knowledge of cash generation activities requires adequate methodology of reporting cash flow and cash flow analysis to be put in place.

The issue of cash generation side of business was treated from various aspects within the international academic literature: relevance of cash flow statement in business plans and analysis [1], cash flow statement is the instrument for monitoring company's financial performance [2], dilemmas and discussions related to the cash flow statement [3], methods used to prepare cash flow statement [4], impact which changes in cash flow have on the stock prices of a company [5], risk of refinancing and its impact on cash item and company's financial policy [6], possibility of predicting cash generation by using rolling forecast [7], influence of cash flow on the growth of company market share [8], connection between the level of intellectual property owned by the company and its strong cash position [9]. The abovementioned papers deal with contemporary issues of cash flows and cash flow statements within the international framework

Authors from our region are increasing their focus on this subject. Vlaović et al [10] have analysed the effect of discounted cash flows on the company market value. Cash flow classification and dilemmas on both domestic and international markets was the subject of research by Stevanović [11]. Stevanović et al [12] analysed the motives and possibility of creative cash flow reporting, while Miletić completed a comparison of direct and indirect reporting of cash flow generated from operating activities [13]. The movement of net profit and free cash flow for certain stocks on the capital market in B\&H was analysed by Alihodžić [14].

No data have been found in academic literature on how much is the cash flow statement used in analysing and planning business operations of companies and whether there are any differences between companies depending on their cash requirements.

Research shown in this paper was conducted with the aim of understanding the current state regarding the influence of different cash requirements, among companies operating in the Republic of Serbia, on certain aspects of cash flow management, preparation of cash flow statements and positions of the management regarding the significance of cash flow in broader sense.

Basic hypothesis $\left(\mathrm{H}_{0}\right)$ is the statement that "in practice there is no difference between companies in respect of the preparation, analysis and application of cash flows and preparation of cash flow statements depending on their cash requirements". 
This hypothesis was tested on the basis of results obtained through research assuming that there is a difference in the application and analysis of cash flow and cash flow statements depending on their cash requirements.

$\mathrm{H}_{0}-\quad$ there are no differences between companies having different cash requirement, that are operating in the Republic of Serbia, in terms of management practices, preparation and analysis of cash flow and cash flow statements.

The hypothesis was tested in relation to the following assumptions:

$\mathrm{H}_{01}$ - there are no differences among companies having different cash requirements in respect of their position that future cash flows are key factor for determining the company market value;

$\mathrm{H}_{02}$ - there are no differences among companies having different cash requirements in respect of their position that cash flow statement is complementary to income statement and balance sheet;

$\mathrm{H}_{03}$ - there are no differences among companies having different cash requirements in respect of the practice of preparing periodic cash flow statements in the course of the business year;

If statistical analysis shows that probability of non-existent difference among companies having different cash requirements is within the $95-99 \%$ range $(\mathrm{p}=0.05 ; \mathrm{p}=0.01)$, alternative hypothesis may be accepted that there are differences among companies having different cash requirements in regard to the aspect of cash management and cash flow statement which is the subject of observation.

\section{METHODS}

Research was conducted by means of questionnaire sent to companies on the territory of the Republic of Serbia. The questionnaire results are indicative of the following: position of the respondents regarding the statement that the future cash flows are the key factor for determining company's market value, importance of the cash flow statement as the supplementary and complementary to the income statement and balance sheet and that periodic cash flow statements should be prepared in the course of the business year. All these issues were examined from the stand point of the cash requirements of individual companies which are defined as continuous or seasonal cash requirements.

The method applied was the ad hoc sample taken from the database kept by the Regional Chamber of Commerce Novi Sad. The representative sample covered 250 companies. $21.60 \%$ of questionnaires were filled in and returned which is considered an acceptable response rate. The questionnaire was distributed electronically.
Statistical processing of data was conducted by analysing the frequency of answers chosen in the entire sample and among companies classified according to their cash flow requirements. Statistical significance of the difference in frequency of certain answers chosen by companies having continuous and seasonal cash requirements and by companies that have not defined their cash requirements was tested by using Chi-squared test. The results obtained by statistical analysis are presented through probability that answers chosen by the companies having different cash requirements profiles do not differ $(p)$.

\section{RESULTS AND DISCUSSIONS}

Presentation and discussion of the results obtained through research revealed the current state in the Republic of Serbia regarding the position that future cash flow as the key factor for determining company market value, the position that cash flow statement is complementary to income statement and balance sheet and also regarding periodic preparation of the cash flow statements in the course of the business year.

Future cash flows as the key factor for determining company market value represents an important position resulting from the role that cash flow has in business analysis and assessment of company market value. Table 1 shows the percentage of those agreeing, partially agreeing and disagreeing with this position depending on the cash requirements of their companies taken from the sample.

The test was supposed to show the influence which the nature of cash requirements in a company has on the positions of the respondents and their agreement with the role and significance of future cash flows generated by the company as the single most important factor for determining company market value. Based on results obtained, the following can be observed:

Half of the respondents from the companies having continuous cash requirements show partial agreement with the position that future cash flows are the key factor for determining the company market value whereas more than a third of respondents from this group expressed agreement with this position.

In the sample under analysis, more than half of the respondents from the companies having seasonal cash requirements express agreement with the position that future cash flows are the key factor for determining the company market value with equal distribution of their answers between the remaining two options.

Respondents from companies that do not define their cash requirements chose to disagree with the said position. Three quarters of the respondents from this group opted for it.

We can conclude from the foregoing that the testing of the $\mathrm{H} 01$ hypothesis that the future cash flows is the key factor for determining the company market value among the companies having different cash requirements, by using Chi-squared test, shows that the probability of this hypothesis being true is extremely small $(\mathrm{p}=0.01454)$ and therefore alternative hypothesis

Future cash flows as the key factor for determining company market value

\begin{tabular}{|c|c|c|c|}
\hline \multirow{2}{*}{$\begin{array}{l}\text { Cash requirements of a } \\
\text { company }\end{array}$} & \multicolumn{3}{|r|}{ Hel valu } \\
\hline & I agree & I partially agree & I disagree \\
\hline Continuous cash requirements & $37,50 \%$ & $50,00 \%$ & $12,50 \%$ \\
\hline Seasonal cash requirements & $60,00 \%$ & $20,00 \%$ & $20,00 \%$ \\
\hline Unknown & $0,00 \%$ & $25,00 \%$ & $75,00 \%$ \\
\hline
\end{tabular}

Table 1: Company's cash requirements and the position that the future cash flows is the key factor for determining company market value $\left(\mathrm{P}=0.01454^{\star}\right)$

${ }^{\star}$ Probability that there is no difference between the sampled companies having different cash requirements 


\begin{tabular}{|c|c|c|c|}
\hline \multirow{2}{*}{$\begin{array}{l}\text { Company's cash } \\
\text { requirements }\end{array}$} & \multicolumn{3}{|c|}{ Cash Flow Statement - whether it is complementary to income statement and balance sheet } \\
\hline & Complementary & Unnecessary repetition & I don't know \\
\hline Continuous cash requirements & $76,32 \%$ & $7,89 \%$ & $15,79 \%$ \\
\hline Seasonal cash requirements & $70,00 \%$ & $10,00 \%$ & $20,00 \%$ \\
\hline Unknown & $0,00 \%$ & $100,00 \%$ & $0,00 \%$ \\
\hline
\end{tabular}

Table 2: Cash requirements of a company and position regarding cash flow statement as complementary to income statement and balance sheet $\left(\mathrm{P}=0.0387^{\star}\right)$

${ }^{\star}$ Probability of no difference between the sampled companies having different cash requirements

\begin{tabular}{|c|c|c|c|}
\hline \multirow{2}{*}{$\begin{array}{l}\text { Company's cash } \\
\text { requirements }\end{array}$} & \multicolumn{3}{|c|}{ Periodic preparation of cash flow statement in the course of the business year } \\
\hline & Prepared & Not prepared & I don't know \\
\hline Continuous cash requirements & $67,50 \%$ & $17,50 \%$ & $15,00 \%$ \\
\hline Seasonal cash requirements & $90,00 \%$ & $10,00 \%$ & $0,00 \%$ \\
\hline Unknown & $25,00 \%$ & $75,00 \%$ & $0,00 \%$ \\
\hline
\end{tabular}

Table 3: Cash requirements of a company and periodic preparation of cash flow statement in the course of the business year $\left(\mathrm{P}=0.03370^{*}\right)$

${ }^{*}$ Probability of no difference between the sampled companies having different cash requirements

can be accepted that there is large diversity in opinions between companies having different cash flow requirements.

Cash flow statement is complementary to income statement and balance sheet (Table 2). This position is indicative of the different nature of cash flow statement compared to income statement and balance sheet but also their interconnection which is precisely how the notion of complementary was used here.

Research into the impact which the cash requirements of a company have on the cash flow statement within the financial reporting established the following:

Company's which have continuous and seasonal cash requirements had proportionately similar results. Contrary to them, the respondents from the sample who are not familiar with the cash requirements of their companies showed entirely negative position regarding the complementary nature of cash flow statement to the income statement and balance sheet.

The said results are indicative of the position that testing of the H02 hypothesis that there is no difference in the opinions of the respondents regarding the position that cash flow statement provides complementary information to income statement and balance sheet among companies having different cash requirements, by using Chi-squared test, shows that the probability $(\mathrm{p}=0.0387)$ of this hypothesis being true is extremely small ( $\mathrm{p}=0.0387)$, and therefore an alternative hypothesis can be accepted that there is significant difference in positions between the respondents from companies having different cash requirements.

Position regarding the periodic preparation of the cash flow statement in the course of the business year is significant for estimating the importance of its use in managing a company but also for assessment of the quality of the cash flow statements themselves. Table 3 shows the percentage of companies that prepare cash flow statement several times in the course of the business year and those that don't prepare them depending on their cash requirements.

The results obtained from the tested sample regarding companies having different cash requirements and practicing peri- odic preparation of the cash flow statements are indicative of the following:

Almost all companies having seasonal cash requirements practice periodic preparation of the cash flow statements in the course of the business year. Likewise, results show that more than half of companies having continuous cash requirements practice the preparation of cash flow statement in the course of the business years. This is undoubtedly a positive finding because regular preparation of cash flow statements and their use for management purposes contributes to better quality of business decisions which is precisely the aim of these reports while on the other hand, they improve the practice of preparation and interpretation of the cash flow statements.

Respondents from the companies that do not define their cash requirements almost entirely took the position that their companies do not prepare cash flow statements.

The said results are indicative of the position that testing of the H03 hypothesis, there is no difference in the opinions of the respondents regarding the preparation of cash flow statements in the course of the business year among the companies having different cash requirements, by using Chi-squared test, shows that the probability ( $\mathrm{p}=0.0337$ ) of this hypothesis being true is extremely small $(\mathrm{p}=0.0387)$, and therefore an alternative hypothesis may be accepted that there is significant difference in positions between the respondents from companies having different cash requirements.

\section{CONCLUSION}

The conducted research describes the knowledge of cash flows and use of cash flow statements in respect of cash requirements of companies operating in the Republic of Serbia taken from a representative sample.

General conclusion regarding the future cash flows as the key factor for determining company market value is that the majority of respondents from the companies having continuous cash requirements partially agree with the position, majority of respondents from companies having seasonal cash 
requirements completely agree with the said position while the majority of respondents from companies which do not define their cash requirements expressed disagreement with the said position.

In respect of the cash flow statement being complementary to other financial statements, the results show that the majority of respondents from the companies having continuous and seasonal cash requirements expressed agreement with the position that cash flow statement is complementary to income statement and balance sheet. Respondents from the companies that do not define their cash requirements expressed disagreement with the said position.

In respect of periodic preparation of the cash flow statements, majority of respondents from the companies having continuous cash requirements expressed agreement with the practice of periodic preparation of cash flow statement in the course of the business year. Respondents from the companies having seasonal cash requirements expressed high level of agreement with the said practices. On the other hand, respondents from the companies that do not define their cash requirements expressed high level of disagreement with the practice of preparing periodic cash flow statements.

The said results speak of the necessity of enlightening the managers and those responsible for the preparation of financial statements about the significance of cash flows in business cycles of the company and the necessity of regular preparation and analysis of the cash flow statements for financial reporting. This can only be achieved through continuous education in seminars, high quality articles in domestic professional literature and by dedicating more lessons on cash flow and financial reporting within the formal educational system.

\section{REFERENCES}

[1] Staubus, J. G. (1989). Cash Flow Accounting and Liquidity: Cash Flow Potential and Wealth. Accounting and Business Research, 19(74), 161-169. Retrieved from Business Source Premier, EBSCOhost.

[2] Boussard, D., \& Colasse, B. (1992). Funds-flow statements and cash-flow accounting in France Evolution and significance. European Accounting Review, 1(2), 229-254. Retrieved from Business Source Premier, EBSCOhost.
[3] Broome, O. W. (2004). Statement of Cash Flows: Time for Change! Financial Analysts Journal of CFA Institute, 60(2), 16-22. Retrieved from http://www.cfapubs.org/toc/ faj/2004/60/2.

[4] Hales, J., \& Orpurt, F. S. (2013). A Review of Academic Research on the Reporting of Cash Flows from Operations. Accounting Horizons, 27(3), 539-578. doi: 10.2308/acch50498

[5] Chen, J., \& Shane, P. B. (2014). Changes in Cash: Persistence and Pricing Implications. Journal Of Accounting Research, 52(3), 599-634. doi:10.1111/1475-679X.12050

[6] Harford, J., Klasa, S., \& Maxwell, W. F. (2014). Refinancing Risk and Cash Holdings. Journal Of Finance, 69(3), 9751012. doi:10.1111/jofi.12133

[7] Alltizer, R. L., \& Swanson, Z. L. (2014). Cash Position Forecasts Pre and Post the 2008 Market Crash. Journal Of Business Strategies, 31(1), 205-220.

[8] Hongchao, Z. (2014). ON THE TRENDS IN CASH HOLDINGS. Academy Of Accounting \& Financial Studies Journal, 18(1), 115-128.

[9] Lin, S. (2014). Why do firms hold so much cash? An innovation explanation. Canadian Journal Of Administrative Sciences (John Wiley \& Sons, Inc.), 31(1), 3-17. doi:10.1002/ cjas. 1273

[10 ] Vlaović-Begović, S., Momčilović, M., \& Jovin, S. (2013). Advantages and limitations of the discounted cash flow to firm valuation. Škola biznisa, (1), 38-47. Retrieved from http://scindeks-clanci.ceon.rs/data/pdf/14516551/2013/1451-65511301038V.pdf

[11] Stevanović S. (2013). Classification of cash flows: Dilemmas in international and domestic practices. Računovodstvo, 57(3-4), 30-37.

[12] Stevanović, S., Belopavlović, G., \& Lazarević-Moravčević, M. (2013). Creative cash flow reporting: The motivation and opportunities. Economic Analysis, 46(1-2), 28-39.

[13] Miletić, D. (2011). Direktan i indirektan metod sastavljanja izveštaja o tokovima gotovine iz poslovnih aktivnosti - komparativan pristup. Računovodstvo, 55(11-12), 75-86.

[14] Alihodžić, A. (2013). Analysis of change in net income and free cash flow for shares in B\&H capital market. Tržište, novac, kapital, 46(3), 22-36.

\title{
UPRAVLJANJE TOKOVIMA GOTOVINE U SAVREMENOM NAČINU POSLOVANJA U REPUBLICI SRBIJI
}

\author{
Marko Milojević ${ }^{1}$, Dragan Miletić ${ }^{2}$ \\ ${ }^{1}$ Poslovni fakultet u Beogradu, Univerzitet Singidunum, Danijelova 32, Beograd, Srbija, mmilojevic@singidunum.ac.rs \\ ${ }^{2}$ Schneider Electric DMS NS, Narodnog fronta 25 A,B,C,D, Novi Sad, Srbija, dragmil67@gmail.com
}

\section{Apstrakt:}

Savremeno upravljanje kompanijama pretpostavlja upravljanje tokovima gotovine kao jednim od najvažnijih instrumenata za praćenje i kontrolu normalnog funkcionisanja poslovanja. Adekvatno upravljanje tokovima gotovine bazira se na pravilnom sastavljanju izveštaja o tokovima gotovine i njegovom tumačenju. Da bi se utvrdila adekvatnost korišćenja ovog izveštaja i značaja koji se pridaje upravljanju tokovima gotovine, kao univerzalno primenljivog znanja i veštine, sprovedeno je istraživanje kod domaćih kompanija putem ankete. Razmatran je uticaj različitog profila potreba za gotovinom preduzeća u odnosu na različite aspekte analize tokova gotovine. Dobijeni rezultati upućuju da ispitanici sa kontinuiranim i sezonskim profilom potreba za gotovinom pokazuju zadovoljavajuće poznavanje predmeta istraživanja i iskazuju stavove koji su u potpunosti ili delimično afirmativni u odnosu na: buduće tokove gotovine kao glavne determinante vrednosti privrednog subjekta, stav o komplementarnosti izveštaja o tokovima gotovine u odnosu na bilans uspeha i bilans stanja i praksu sastavljanja izveštaja o tokovima gotovine tokom poslovne godine. Preduzeća koja nisu profilisala svoje potrebe za gotovinom u upitniku iskazuju neslaganje sa navedenim stavovima što predstavlja iskaz o njihovom nedovoljnom nivou poznavanja gotovinske osnove finansijskog izveštavanja. Nelikvidnost domaće privrede i zatečeno stanje nalažu neophodnost podizanja kvaliteta znanja i veština u upravljanju tokovima gotovine zasnovanih na kvalitetnim izveštajima o tokovima gotovine i pratećoj analizi.

\section{Ključne reči:}

upravljanje tokovima gotovine, analiza tokova gotovine, izveštaj o tokovima gotovine, profil potreba za gotovinom preduzeća,

budući tokovi gotovine, komplementarnost. 